\title{
LOS JUGLARES, CORNAMUSAS DEL DIABLO: \\ LAS REPERCUSIONES ICONOGRÁFICAS \\ DE LA CONDENA DE LOS ENTRETENEDORES
}

\author{
Sandra Pietrini \\ Università degli Studi di Trento \\ sandra.pietrini@unitn.it
}

\begin{abstract}
Resum
Los juglares fueron condenados por los escritores cristianos durante toda la época medieval. La transformación del aspecto natural, considerada como un pecado contra Dios, implicó una reprobación particular contra los acróbatas, danzadores y contorsionistas. Estas tipologías de juglares han sido frecuentemente representadas en la iconografía del los siglos XIII y xIV, en las esculturas de las iglesias así como en las miniaturas de los manuscritos. Los múltiples documentos figurativos muestran en diversa manera y grado las repercusiones de estas condenas, con una frecuente asimilación entre los juglares y los animales mas torpes y despreciables, como el mono, que hacen de intermediarios entre los hombres y el diablo. Instrumentos degenerados del demonio, los entretenedores deshonran la dignidad de la naturaleza humana y entonces son representados como seres deformes, bestiales y demoníacos.
\end{abstract}

\section{Paraules clau}

Juglares medievales, iconografía, condenas morales.

\begin{abstract}
Throughout the Middle Ages, Christian writers condemned jesters because of the ways in which they contorted and thus altered their bodies. Considered sins against God, these practices engendered particular disapproval of acrobats, dancers, and contortionists. These types of jesters appear frequently in 13 th and I4th century iconography in the form of carved reliefs found in churches and miniatures encountered in manuscripts. These diverse figurative documents display the repercussions of scholarly condemnations in various ways and degrees, especially by means of frequent associations between jesters and the baser and more despicable animals, such as apes, seen as playing an intermediate role between humans and the devil. As degenerated instruments of the devil, such entertainers dishonoured human dignity and were therefore represented as deformed, bestial, and demonic creatures.
\end{abstract}

\section{Keywords}

Medieval jesters, iconography, moral condemnations. 
Por una rara paradoja las fuentes mas útiles para reconstruir la imagen del juglar son las condenas de los escritores cristianos. Desde los Padres de la Iglesia, se suceden las censuras, reprobaciones y anatemas contra los turpi histriones, culpables de alejar a los hombres de la contemplación de los asuntos espirituales para inducirlos a la risa y a la lujuria. Se trata de documentos cargados de prejuicios, que no pueden ser empleados para trazar una imagen digna de consideración acerca de las perfomances efectivas de los entretenedores. Estas fuentes nos cuentan todavía algo esencial sobre la figura del juglar en el imaginario moral de la Edad Media, que ha tenido notables repercusiones sobre las artes figurativas, que a su vez han contribuido a divulgar una idea negativa del teatro y de los espectáculos profanos. Para introducir el tema, pondré dos ejemplos específicos, relacionados con la consideración moral de la danza. Una miniatura del Salterio Rutland, un manuscrito inglés del siglo xiII, representa un hombre desceñido que está bailando, acompañado por un híbrido monstruoso que toca la cornamusa (gaita). ${ }^{I}$ El miniaturista podría haber sacado la inspiración de la última línea del texto, donde se lee: "turbatus sum a voce inimici", es decir, "estoy turbado por la voz del enemigo". De aquí la imagen del tañedor infernal, que por otro lado evoca las palabras del predicador alemán Berthold von Regensburg, que en el mismo siglo xiI define los juglares como "cornamusas del diablo" (tiuvels blâsbelge). ${ }^{2}$ Otra miniatura del manuscrito (f. 65) representa una mujer que anda o baila sobre las manos, mientras un ser monstruoso parece aplaudir su exhibición. [Fig. I] Esta figura también podría representar al diablo, que sugiere su acrobacia a la danzadora, porque, como decía ya en el siglo IV el orador bizantino Juan Crisóstomo, "donde está la danza, está el diablo". ${ }^{3}$ Pero podría representar aun las consecuencias morales que afectan a los que asisten a los espectáculos, cómplices y a la vez víctimas del pecado.

Como ejemplo de interpolación de figuras del imaginario moral se podría mencionar a Salomé, que en la iconografía medieval frecuentemente se representa como una juglaresa que ejecuta acrobacias ${ }^{4}$ [Fig. 2] o complicados malabares con

I Salterio Rutland. London, British Library, ms. Add. 62925, fol. 56v.

2 Apud R. Hammerstein, Diabolus in Musica. Studien zur Ikonographie der Musik im Mittelalter, Bern \& München, I974, p. 5 I.

3 "Ubi enim saltatio, ibi diabolus": G. Crisostomo, Homiliae in Matthaeum, Patrologia Greca 58, p. 49I. Explica que Dios nos ha dado los pies no para emplearlos torpemente, sino para andar rectamente: "Neque enim ideo pedes nobis dedit Deus, ut iis turpiter utamur, sed ut recte gradiamur" (ibidem). De hecho, Crisóstomo afronta la cuestión del baile en relación con el personaje de Salomé, y por ello desemboca en conclusiones tan extremas.

4 Por ejemplo en una Biblia moralizada de fines del siglo xiII (London, British Library, ms. Harley 1527, fol. 29) y en el misal de Jean de Marchel, ilustrado par Pierre de Raimbaucourt y fechado en 1323 (Den Haag, Meermanno-Westreenianum Museum, ms. 78.D.40, fol. I08). 
las espadas. ${ }^{5}$ [Fig. 3] La asimilación traslada claramente la pecaminosidad del personaje a las juglaresas, cuya exhibición alude a la lujuria y a la concepción de la mujer como instrumento de un crimen.

Los documentos figurativos útiles para reconstruir la imagen del juglar son muy heterogéneos, y van de los objetos a las esculturas de las iglesias. La mayoría de las fuentes son miniaturas, contenidas en manuscritos de carácter devocional, como los salterios, o literario e histórico como las novelas y las crónicas. Mientras las esculturas eran destinadas a la edificación de los fieles, los manuscritos se reservaban a una élite que sabía leer y comprender las eventuales alusiones a una tradición culta. Tal vez las miniaturas marginales incluyen más de un nivel de interpretación, de la representación realista a la alegoría. Escenas realistas, cómicas y fantásticas de diverso género, híbridos y criaturas deformes pueblan los márgenes de los manuscritos góticos. Este pululante mundo de las drôleries comprende también los tañedores y juglares, identificables por sus acciones más que por sus trajes, porque el típico uniforme de la locura aparece en la iconografía muy tarde, en el siglo xiv (y, antes, dentro de un contexto específico, en la ilustración del Salmo 52, Dixit insipiens). ${ }^{6}$

Como la mayoría de estas miniaturas están contenidas en códices de carácter devocional, parece que no tengan ninguna relación con el texto. Michel Camille ha tratado de explicar la proliferación de obscaena e imágenes vulgares identificando posibles relaciones con las palabras del texto, deliberadamente malentendidas por el miniaturista en función de la comicidad (la separación del latín cul-pa, por ejemplo, habría inspirado el dibujo de un hombre con el culo al aire). Los miniaturistas gozaban en efecto de una gran libertad en la decoración de los márgenes, mientras que la ilustración de la inicial seguía habitualmente lo establecido por el comitente. Pero no siempre se pueden atribuir intenciones tan claras a los artistas, que se remitían sobre todo a su fantasía y utilizaban libremente tipologías y modelos en circulación. Sobre el riesgo de malinterpretar las miniaturas marginales como alusiones sexuales o escatológicas, o como parodias de determinadas categorías nos previene Jean Wirth en su ponderado estudio Les marges à drôleries des manuscrits gothique. ${ }^{7}$ En definitiva, cada imagen tiene que ser considerada e

5 Como en un salterio del siglo XII (Oxford, Bodleian Library, ms. Auct. D.2.6, fol. I66v).

6 Sobre este tema véase S. Pietrini, "Medieval Fools in Biblical Iconography", Medieval English Theatre, 24 (2002), pp. 79-I03, y "Stolti, buffoni e chierici nell'iconograpfia medievale", Quaderni Medievali, 56 (dicembre 200), pp. I4-56, donde aparecen citados otras artículos anteriores sobre el insipiens; T. SAffioti, "L'insipiens del Salmo 52: da folle medievale a buffone di corte", a La scena assente? Realtà e leggenda sul teatro nel Medioevo, Atti del Convegno di Studi (Siena, Certosa di Pontignano, 13-I6 giugno 2004), Alessandria, 2006, pp. 417-448.

7 J. WirTh, Les marges à drôleries des manuscrits gotiques (I250-I350), Genève, 2008. 
interpretada dentro de su contexto especifico, fuere manuscrito o arquitectónico, estimando atentamente los posibles niveles de lectura concebidos por el artista.

Volvamos ahora al tema específico de mi intervención: las repercusiones iconográficas de las condenas hacia los juglares, empezando con algunos ejemplos significativos en la escultura de las iglesias románicas. Representaciones de muy diverso género, tal vez satíricas u obscenas, se encuentran también en el interior de las catedrales, en las decoraciones de los capiteles, y más frecuentemente en lugares marginales y no accesibles a los fieles, como las sillas del coro o misericordias.

Aunque los temas profanos parecen digresiones gratuitas, su significado tiene que estar relacionado con el orden arquitectónico e iconográfico general. Su colocación marginal, por ejemplo, puede ser interpretada como una alusión a la alteridad y a la diversidad que amenaza los límites del mundo cotidiano. ${ }^{8}$ Monstruos y demonios que simbolizan el pecado amenazan a los fieles hasta el perímetro protegido del edificio sagrado. No es extraño que a veces vayan acompañados por tañedores de instrumentos, acróbatas y danzadores, seres disolutos y marginales que los escritores cristianos consideraban aliados del diablo. En el siglo XII Honorio de Autun define por ejemplo a los juglares como ministri Satanae y los juzga privados de cualquier esperanza de salvación. ${ }^{9}$ En particular los acróbatas y contorsionistas, que trastornan su aspecto natural, hasta hacerse semejantes a los monstruos colocados en los márgenes de la creación, cuya deformidad es un signo de vileza moral.

En un capitel de la iglesia de Anzy-le-Duc, junto al acróbata que hace el puente son representadas dos serpientes, símbolos recurrentes de lujuria, [Fig. 4] y en un capitel de la iglesia de Sainte Madeleine, [Fig. 5] en Vézelay, el tañedor es acompañado por un demonio que lo mira mientras toca el pecho de una mujer. La música de los juglares convoca a las potencias infernales, porque es un arte pecaminoso y, como vamos a ver más adelante, fundado sobre el usus y no sobre un conocimiento teórico de las reglas de la armonía musical. Y como decía San

8 A partir de un cotejo de casi 500 documentos figurativos de la pintura mural danesa de los siglos XIV y xv, Katrin Kröll he llegado a esta conclusión: más del setenta por ciento de los temas profanos son colocados en una posición marginal en relación a los temas sagrados. Creo que a las mismas conclusiones se podría llegar con un análisis de los edificios religiosos de los otros países de Europa: K. KRÖLL, "Die Komik des grotesken Körpers in der christlichen Bildkunst des Mittelalters. Eine Einführung”, a K. KRöll y H. STEGer (eds.), Mein ganzer Körper ist Gesicht. Groteske Darstellungen in der europäischen Kunst und Literatur des Mittelalters, Freiburg im Breisgau, I994, pp. II-IO5, p. 43.

9 "D. [Discipulus] Habent spem joculatores? - M. [Magister] Nullam: tota namque intentione sunt ministri Satanae": Onorio D’Autun, Elucidarium sive dialogus de summa totius christianae theologiae, II (Patrologia Latina, I72, p. II48). 
Agustín refiriéndose a los cantores que deberían conocer la música, "el hombre es mejor que las bestias solo cuando sabe lo que hace"

Un tema iconográfico recurrente en los capiteles de las iglesias de Alvernia, en el sur de Francia, es el cazador con un mono atado o encadenado. ${ }^{\text {II }}$ [Fig. 6] Podría estar inspirado en las historias de captura, que en el siglo XII estaban bastante difundidas, pero también en los juglares que exhibían monos amaestrados. ${ }^{12}$ Según algunos investigadores el tema tiene también un alcance metafórico, relacionado con la idea - ya presente en el Physiologus y reiterada en los bestiarios medievales - que el mono representa simbólicamente al diablo. ${ }^{13}$ En este caso, su fealdad y deformidad son interpretadas como indicio de una semejanza con el maligno, mientras que el hecho que no tenga cola, significa que no tendrá un buen fin, es decir una vida eterna.

De hecho algunas imágenes presentan detalles inquietantes. En un capitel de la iglesia de Droiturier, [Fig. 7] el animal tiene los genitales bien visibles mientras el hombre tiene en su mano un martillo y unas tenazas, quizás instrumentos simbólicos para una castración-extirpación del mal. Para confirmar el carácter demoníaco de la escena, detrás del mono se ve la cabeza de un monstruo que abre sus fauces.

Otras figuraciones presentan una connotación espectacular bastante clara. En un capitel de la iglesia francesa de Saint-Genou están representados dos amaestradores de monos: uno con un vestido ceñido y con capucha en la punta, el otro con una porra en la mano. [Fig. 8] Los dos monos aparecen encadenados y visiblemente espantados: uno está en pie sobre un cerdito, el otro es obligado a mantenerse en equilibrio sobre dos esferas. La connotación cómica y casi grotesca de la escena non excluye una interpretación en llave simbólica. Uno de los domadores parece sonreír diabólicamente, el otro tiene la cabeza pelada, detalle que alude a características negativas. Ambos presentan un aspecto bestial, mientras los monos asumen posturas humanas, en una interesante ósmosis metamórfica

io Agostino, De ordine, II, I9: "Deinde quis bonus cantator, etiamsi musicae sit imperitus, non ipso sensu naturali et rhythmum et melos perceptum memoria custodiat in canendo, quo quid fieri numerosius potest? Hoc nescit indoctus, sed tamen facit operante natura. Quando autem melior et pecoribus praeponendus? quando novit, quod faciat. Nihil aliud me pecori praeponit, nisi quod rationale animal sum" (Corpus Christianorum. Series Latina, 29).

II Por ejemplo en las abadías e iglesias de Mozac, Biozat y Montfermy. Estas esculturas son muy similares y Swiechowski cree que sean inspiradas al capitel de Mozac: Z. Swiechowski, Sculpture Romane d'Auvergne, trad. francésa de L. Carminati-Nawrocka y A. Zarynowa, Clermont Ferrand, 1973, p. 195.

I2 Esta es la opinión de P. QuArré, "Le thème du singe tenu en laisse par l'homme dans les églises romanes de la Haute Auvergne", Bulletin de la Société Nationale des Antiquaires de France (1938), pp. $155-160$.

I3 V.-H. Debidour, Le Bestiaire sculpté du Moyen Âge en France, Paris, Arthaud, 196I, pp. 260-26I. 
de signos (los monos tienen, por ejemplo, cabellos, mientras este elemento típico de la humanidad es eliminado de la representación de los amaestradores). Evidentes víctimas de una coerción, los monos pueden simbolizar el pecador sujeto a las potencias infernales, es decir al demonio, del cual los dos juglares son dignos representantes. Los domadores son hombres degenerados y convertidos en bestiales por el pecado: desfigurada su imagen natural y perdida su dignidad, se transforman en grotescos instrumentos del demonio, parecidos a los animales que emplean en sus espectáculos. Esta asimilación entre juglares y monos no se encuentra solo en la iconografía, sino también en las fuentes literarias. Como es sabido, el mono es un animal que imita todo y durante la Edad Media el concepto de mimesis o imitación tiene una acepción negativa. El diablo también es considerado una simia Dei, porque en su presunción de omnipotencia intenta inútilmente imitar a Dios.

Al empezar del siglo xIII, Alexander Neckam afirma que el mono es como el hipócrita que imita los signos característicos de la virtud y asimila el juglar a este animal:

No es de verdad que el histrión, que muestra un rostro ora sonriente ora lloroso, y cambia su aspecto en todas las formas posibles para incitar la risa de los que lo observan, parece comportarse como un mono? (...) La acción del histrión deshonra la dignidad de su naturaleza, a cambio de un miserable provecho. ${ }^{14}$

Como el simio, el juglar es un instrumento diabólico que lleva a los hombres a la perdición a través de la diversión. Otro ejemplo literario. También en el siglo XIII, el fraile dominico Guglielmo Peraldo asimila el bufón (scurra) a la cabra y al mono, "con los cuales se entretiene el diablo, induciendo a los hombres a la risa", que considera una ebullición de la concupiscencia. ${ }^{\text {Is }}$ Mientras la cabra es tradicionalmente asociada a la lujuria, la similitud entre el bufón y el mono se basa en la idea de la deformidad: alterando el propio aspecto, el juglar va contra natura convirtiéndose en una bestia despreciable.

\footnotetext{
I4 Nonne item histrio nunc lugentis vultum praetendens nunc ridentis, vultumque in diversa commutans, ut inspicientes ad risum compellat vel invitos, simiae officium gerere videtur? Vae, vae! Nobilis creatura homo videri simia laborat. Naturae dignitatem dehonestat histrionatus, ob infelicis lucelli turpem quaestum": AleXander Neckam, De naturis rerum libri duo, ed. T. Wright, London, 1863, p. 210.

I5 "Notandum ergo quòd scurra est velut capra, vel simia, cum quibus ludit diabolus, \& homines excitat ad risum. Capra animal foetidum est. Simia animal deforme. Sic tales valde foetidi sunt \& valde deformes": Guglielmo Peraldo, Summa virtutum, ac vitiorum, Lugduni, Gulielmum Rovillium, 1585 , p. 589 (pero es p. 590).
} 
En la iconografía, las repercusiones de la concepción negativa de los juglares adquieren tal vez una connotación satírico-paródica. ${ }^{16}$ Las representaciones de simios músicos o acróbatas, por ejemplo, pueden ser interpretadas como una parodia de los juglares. Pero detrás de la parodia, se vislumbra una posible alusión a la degeneración moral. En una misericordia de la catedral de Norwich se puede ver una escultura ridícula y obscena, que parece ilustrar perfectamente la metáfora icástica de Berthold von Regensburg de los juglares como cornamusas del diablo. [Fig. 9] El mono músico aparece disfrazado de juglar, con su capuchón típico, y emplea otro animal (mono o perro) como un instrumento musical, poniéndose su cola en la boca para tocarla como una cornamusa. Un perro que deforma su figura en una risa antinatural que acompaña la escena. El artista ha sacado inspiración del doble sentido obsceno de la cornamusa, ${ }^{17}$ recurriendo además a la imagen degradada del mono-juglar para sugerir una analogía densa de reprobación moral.

En una miniatura del Roman d'Alexandre, el mono músico que acompaña la partida de ajedrez de un caballero y una dama ejecuta una torsión del cuerpo [Fig. Io] ${ }^{18}$ es decir, añade a la actividad musical una alteración de su aspecto — hecho considerado por la Iglesia un grave pecado- y remite a la imagen de la serpiente por la lengua larga y sutil que sale de su boca abierta en el canto. Por otra parte el mono toca un hueso de mandíbula, objeto que se encuentra también en otras representaciones paródicas de tañedores, híbridos y sirenas. ${ }^{19}$ [Fig. II]

I6 Por ejemplo en la miniatura de un breviario franco-flamenco de fines del siglo XIII, donde junto a un burro que toca la viola se figura un mono malabarista que lanza al aire tres espadas: Baltimore, Walters Art Gallery, ms. I09, fol. 20.

I7 Sobre el sentido simbólico de los instrumentos tocados por híbridos y bestias en las marginalia véase M. Cluzot, "La musique des marges. L'iconographie des animaux et des êtres hybrides musiciens dans les manuscrits enluminés du XII ${ }^{\mathrm{e}}$ au XIV siècle", Cahiers de civilisation médiévale, 42 (1999), pp. 325-342. Sobre la cornamusa, cfr. P. BEC, La Cornemuse. Sens et histoire des ses désignations, Toulouse, 1996.

I8 Roman d'Alexandre, Oxford, Bodleian Library, ms. Bodley 264, fol. II2. La ilustración del manuscrito, terminada en el I344, es obra de Jehan de Grise y su atelier. Las miniaturas marginales están inspiradas en los entretenimientos de la corte, en los bailes, actuaciones musicales y acrobacias. Algunos estudiosos han visto en estas escenas alusiones al texto o a las ilustraciones principales, es decir una puesta en discusión de los valores dominantes o como una parodia de las acciones valerosas de los caballeros (véase en particular S. K. Davenport, "Illustrations Direct and Oblique in the Margins of an Alexander Romance of Oxford", Journal of the Warburg and Courtauld Institute, 34 (197I), pp. 83-95. Philippe Ménard, por el contrario, he redimensionado el nombre de las posibles referencias al texto en las miniaturas marginales, afirmando que los artistas nunca habrían osado burlarse de la obra que ilustraban ni de un noble personaje como Alejandro Magno: Ph. Ménard, "Les illustrations marginales du Roman d'Alexandre (Oxford, Bodleian Library, Bodley 264)", Risus Mediaevalis: Laughter in Medieval Literature and Art, ed. H. Braet, G. Latré, W. Verbeke, Leuven, 2003, pp. 75-II8.

I9 Por ejemplo en la miniatura de un manuscrito de Jacques de Longuyon, Voeux du Paon. New 
La parodia de los instrumentos musicales es en efecto recurrente en los manuscritos flamencos del siglo XIII, donde la viola es por ejemplo remplazada para un fajo de zarzas y el arco por un rastrillo. ${ }^{20}$ [Fig. I2] Pero ¿̇de dónde viene el hueso mandibular? [Fig. Io] Según la tradición, Caín mató a Abel con la quijada de un asno y se puede precisar que en las más antiguas representaciones orientales de instrumentos agrícolas el hueso mandibular tenia la función de una hoz ${ }^{21}$. El hueso representado en las miniaturas góticas aludiría pues a un instrumento agrícola empleado impropiamente, pero también remite al crimen de Caín.

Tal vez la parodia de los instrumentos musicales parece combinarse con alusiones a la pecaminosidad de las 'performances' juglarescas. En una miniatura del Libro de Horas de Maastricht —un minúsculo manuscrito del año I300, del tamaño de la palma de la mano y riquísimo de ilustraciones en los márgenes - un simio a horcajadas de un jabalí toca un cucharón como si fuera una trompeta. $^{22}$ [Fig. 13] Viste un manto rojo típicamente juglaresco y monta un animal salvaje que, como se lee en la Biblia, devasta la viñas (Salmos, 79, I4), es decir arruina las frutos del Señor. El sentido negativo del mono músico es subrayado por contraposición con la imagen de un ángel que toca el arpa, representado en el margen inferior del folio. A la música sagrada, que celebra las alabanzas a Dios, se opone la ridícula música profana, que destruye el recogimiento espiritual, porque corrompe los ánimos e instiga al pecado. En otra miniatura del manuscrito (fol. 3I), el sentido metafórico de la asimilación entre juglares y monas es más evidente, como el tañedor de cornamusa que sostiene una danzadora sobre su espaldas, está acompañado por un mono que toca la flauta y el pandero. [Fig. I4]

En las miniaturas góticas los simios que bailan o ejecutan acrobacias están representados frecuentemente al lado de los amaestradores, ${ }^{23}$ [Fig. I5] pero en el caso de la miniatura del Libro de Horas de Maastricht el orden está invertido,

York, Pierpont Morgan Library, William Glazier Collection, ms. 24, fol. I6.

20 Así en un libro de horas franco-flamenco de inicios del siglo xIv: Bruxelles, Bibliothèque Royale, ms. 939I, f. II3v.

2I Esta tradición literaria se difundió al menos a partir del siglo IX y se encuentra en algunas ilustraciones tardomedievales. Sobre la orígen de este detalle véase A. A. BARB, "Cain's Murder-Weapon and Samson's Jawbone of an Ass”, Journal of the Warburg Institute, 35 (1972), pp. 386-389. M. ScHAPIRo, "Cain's Jaw-Bone That Did the First Murder", Art Bulletin, 24 (September 1942), pp. 205-212, propone una explicación fundada sobre algunas analogías lingüísticas. G. Henderson, "Cain’s JawBone", Journal of the Warburg Institute, 24 (196I), pp. I08-II4, afirma por el contrario que el objeto deriva de la iconografía de Sansón y en particular de la mala interpretación del miniaturista de un salterio inglés (London, British Library, ms. Cotton Claudius B.rv).

22 Libro de Horas de Maestricht. London, British Library, ms. Stowe I7, fol. I73v.

23 Por ejemplo en una miniatura del Salterio Luttrell. London, British Museum, ms. Add. 42130, fol. 73, y en una del Salterio Tenison. London, British Library, ms. Add. 24686, fol. I7v. 
porque un animal considerado tonto e inmundo da el ritmo a la danza de los juglares, con un intercambio de funciones que establece una analogía moral.

Los tocadores de instrumentos son la categoría mas representada en las miniaturas medievales. La consideración de la música durante la Edad Media es ambivalente: por un lado goza de un amplio prestigio, porqué es un arte liberal y puede ser utilizada par cantar las alabanzas al Señor — como está demostrado para el tema recurrente de David con el arpa y el de los clérigos cantantes colocados dentro de la inicial del Salmo 97 (Cantate Deum canticum novum). Pero la música de los juglares no era considerada un arte digno de respeto, porque se basaba solo sobre la práctica, es decir el aprendizaje empírico de una técnica, y no sobre las reglas teóricas de la armonía. Los juglares son meros ejecutores : pueden producir sonidos maravillosos pero conocen solo el usus y non dominan la teoría. La mayoría del los tañedores utilizan en efecto instrumentos no afinables, como los de viento y percusión, que están colocados en el grado inferior de la escala jerárquica musical. Alrededor del año Iooo Guido d'Arezzo escribe: "grande es la distancia entre músicos y cantores / estos dicen, aquellos conocen de lo que está compuesta la música / y quien hace lo que no sabe se define como bestia" ${ }^{24}$ Como ya he dicho antes, el mismo concepto había expresado San Agustín para subrayar la importancia de la razón, que distingue al hombre de los animales.

Como la danza, la música del los juglares puede ser también un instrumento de tentación y de instigación al pecado. En los manuscritos medievales la representación de los tañedores de instrumentos es utilizada a menudo para ilustrar el Salmo 97, que empieza con un himno a Dios. En el folio de un salterio de la mitad del siglo XIV, los cantores aparecen enmarcados dentro de un arco gótico, tras del cual hay un edificio que simboliza la abadía o la ciudad; leen un libro puesto sobre un atril y tienen un aspecto muy compuesto ${ }^{25}$. [Fig. I6] De los muros de la abadía sale un personaje que se asoma para escuchar la música de un tocador de viola representado en el borde. El juglar simboliza las tentaciones de la música profana, por la que el hombre es seducido hasta el punto de volver las espaldas a los cantos religiosos.

Recordaremos que una de las peores acusaciones dirigidas a los juglares es la gesticulatio, es decir una gestualidad excesiva, desordenada y grosera. Según la moral cristiana, cada parte del cuerpo fue creada para una función (los pies,

24 "Musicorum et cantorum magna est distantia: / Isti dicunt, illi sciunt, quae componit musica. / Nam qui facit, quod non sapit, diffinitur bestia" (vv. I-3): Guido D’Arezzo, Le opere, ed. A. Rusconi, Firenze, 2005. Ya Aureliano di Réomé, musicógrafo de la mitad del siglo Ix, había subrayado la diferencia entre el músico y el cantor, que asimilaba a la diferencia entre el maestro y el discípulo: "In tantum distare videntur inter se musicus et cantor, quantum magister et discipulus", cit. a T. GÉrold, La musique au Moyen Âge, Paris, 1932, p. 353, n. I.

${ }_{25}$ Oxford, Bodleian Library, ms. Liturg. 198, fol. 9Iv. 
por ejemplo, par andar y no para ejecutar bailes lascivos). Una idea de la mímica juglaresca se puede deducir en negativo de los consejos dados por los escritores cristianos a los jóvenes clérigos y a los monjes cantores, a los que se recomienda evitar los gestos definidos como "histriónicos". Aelredo di Rielvaux critica los cantores de iglesia que gesticulan como juglares: "Tal vez todo el cuerpo se agita con movimientos histriónicos, los labios se retuercen, los ojos dan vueltas, las espaldas se mueven; y a cada nota musical corresponde una flexión de los dedos". ${ }^{26} \mathrm{Y}$ tanto más se agitan, continua Aelredo, más creen servir dignamente al Señor.

Un empleo inmoderado de la gestualidad contraviene el decoro y recuerda la imagen del juglar, similitud negativa por indicar una actitud ridícula. Los escritores y predicadores son conscientes del carácter espectacular de las ceremonias religiosas: los clérigos son actores, en el sentido que se exhiben en acciones y cantos. Pero su autorepresentación debería ser contraria a la de los zafios histriones, que desfiguran su aspecto natural. También el dominico Humberto de Romans traza una imagen caricaturesca de la mímica de algunos frailes, que deforman su cara con expresiones grotescas, y recomienda evitar sobre todo los gestos ridículos, simiescos o imitativos, típicos de los hipócritas y de los juglares. ${ }^{27}$

En las artes figurativas no se encuentran indicios de las descripciones polémicas de la mímica exuberante de los cantores, pero algunas miniaturas revelan la reprobación moral hacia los juglares y la contraposición entre un uso lícito e ilícito de la música y del canto, entre el mundo ordenado de la fe y la diversión profana. El canto de los clérigos del Salmo y la sagrada música de David son frecuentemente acompañados por representaciones de juglares colocados en el exterior de la inicial, como en la miniatura de un salterio inglés del secundo cuarto del siglo XIV [Fig. I7] y en el contemporáneo Salterio Barlow ${ }^{28}$, donde los juglares presentan deformaciones monstruosas. [Fig. I8]

Vamos a ver una ultima miniatura. En el Salterio de Stephen of Derby, los clérigos que leen los cantos sagrados son imitados por dos extraños personajes

26 "Interim histrionicis quibusdam gestibus totum corpus agitatur, torquentur labia, rotant oculi, ludunt humeri; et ad singulas quasque notas digitorum flexus respondet": AELredo DI Rielvaux, De speculo caritatis, II, 23 (Corpus Christianorum. Continuatio Mediaevalis I). El texto será relanzado por Gilbert de Tournai: véase C. Casagrande y S. Vecchio, "L'interdizione del giullare nel vocabolario clericale del XII e del XIII secolo", a Il contributo dei giullari alla drammaturgia italiana delle origini, ed. F. Doglio, Atti del II Convegno di Studio, Viterbo, I7-I9 gingno 1977, Roma, 1978, pp. 207-258, p. 229.

27 "Sunt praeterea mille larvae, mille corrugationes narium, mille contorsiones labiorum, quae decorem disciplinae deturpant, et faciei pulchritudinem quae est speculum disciplinae": Humbert de Romans, Expositio ad regulam Beati Augustini, cit. en C. Casagrande y S. Vecchio, Linterdizione del giullare..., p. 229, nota 67.

28 Oxford, Bodleian Library, ms. Auct. D. 2. 2, fol. Inzv; Salterio Barlow. Oxford, Bodleian Library, ms. Barlow 22, fol. 99. 
dispuestos a leer un librillo fuera de la inicial ilustrada. ${ }^{29}$ [Fig. 19] Uno de ellos viste el típico capuchón en punta de los juglares y es jorobado, es decir marcado por una deficiencia física que alude a la diversidad y a la depravación, porque en el imaginario medieval la deformidad es precisamente un signo de degeneración moral. Corroborando su naturaleza bestial y diabólica, tiene los pies en forma de cascos, como el diablo. El otro juglar también presenta detalles monstruosos. El aspecto ridículo de los dos personajes no debe traer a engaño: tras sus figuras se entrevé el demonio, pero mediatizado por la imagen del juglar, cuya imitación de la postura de los clérigos es un indigno remedo. Como el diablo intenta emular a Dios, así los dos juglares imitan ridículamente la acción de los cantores.

Concluyendo, aunque sea necesario ser muy cautos en la interpretación de las representaciones medievales, un análisis de la iconografía profana pone en evidencia que el imaginario figurativo se resiente y mucho de los prejuicios de la cultura cristiana. Y, un hecho más considerable, a despecho de la tradicional desconfianza hacia la risa y la diversión, la cultura dominante, a través de la figuración, también utiliza la comicidad y la parodia en función del juicio moral, en una interpolación de niveles que parece rara solo a la sensibilidad moderna.

29 Salterio de Stephen of Derby, Oxford, Bodleian Library, ms. Rawlinson G. I85, fol. 8Iv. El manuscrito proviene de la Christ Church Cathedral de Dublin y es datable hacia I348-I374. 


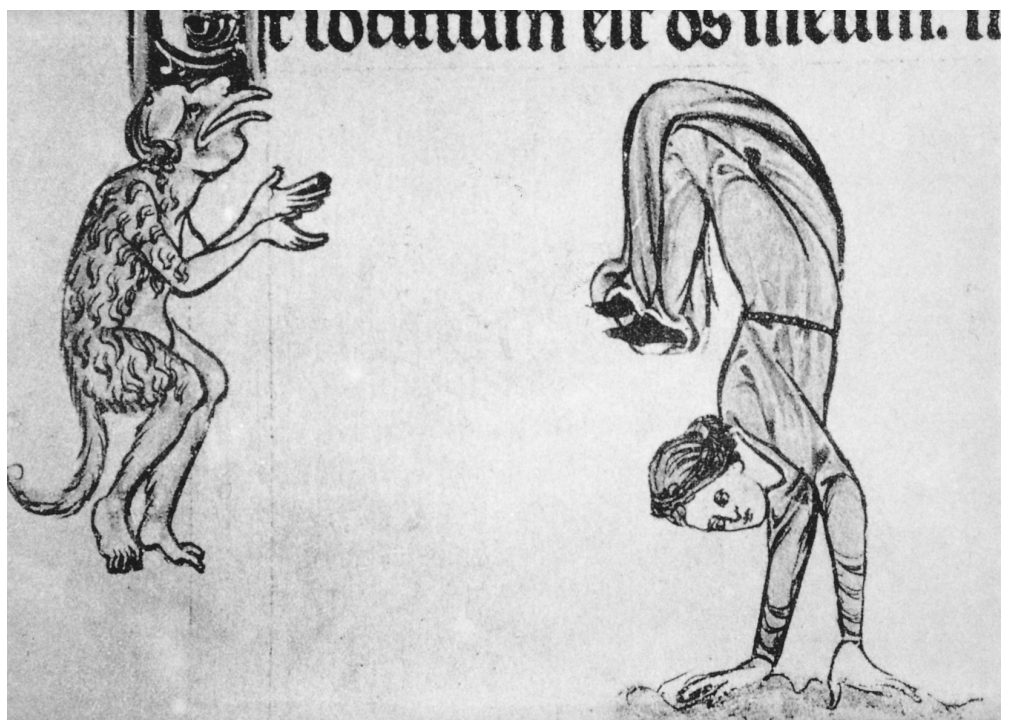

I. Salterio Rutland, London, British Library, ms. Add. 62925, fol. 56v.

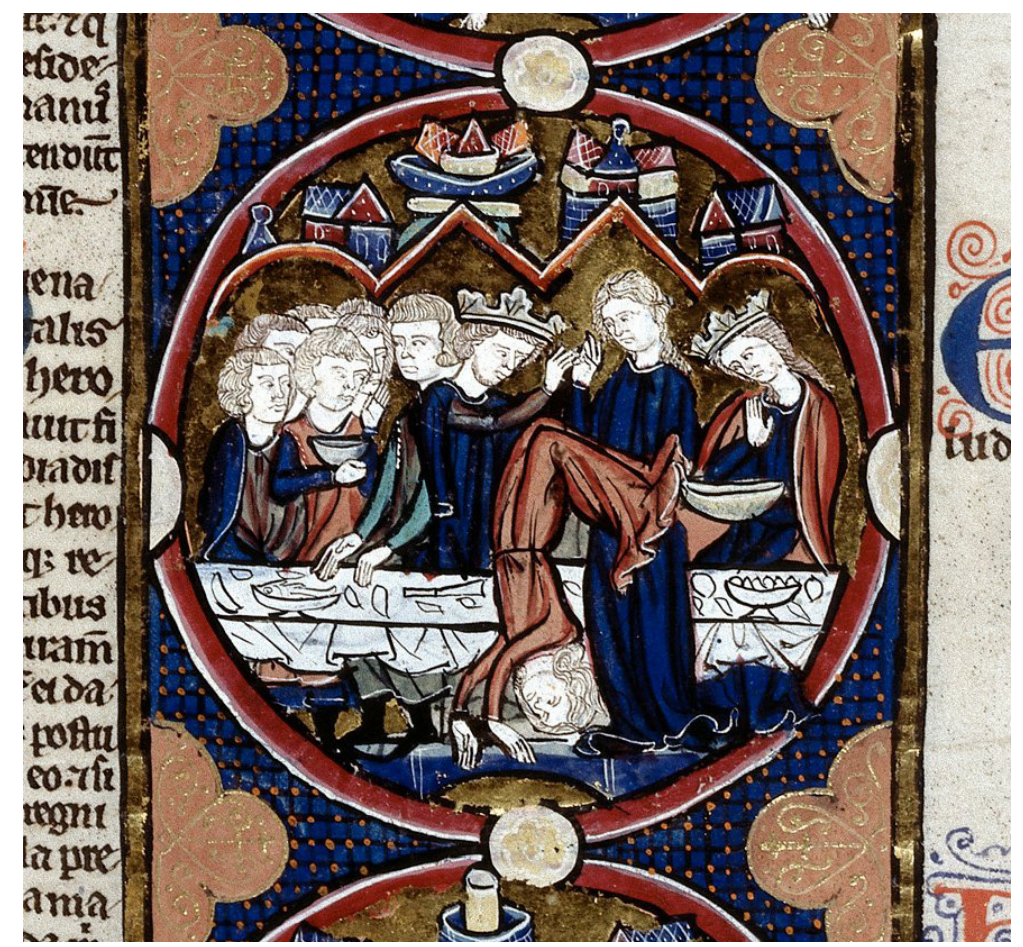

2. London, British Library, ms. Harley I527, fol. 29. 


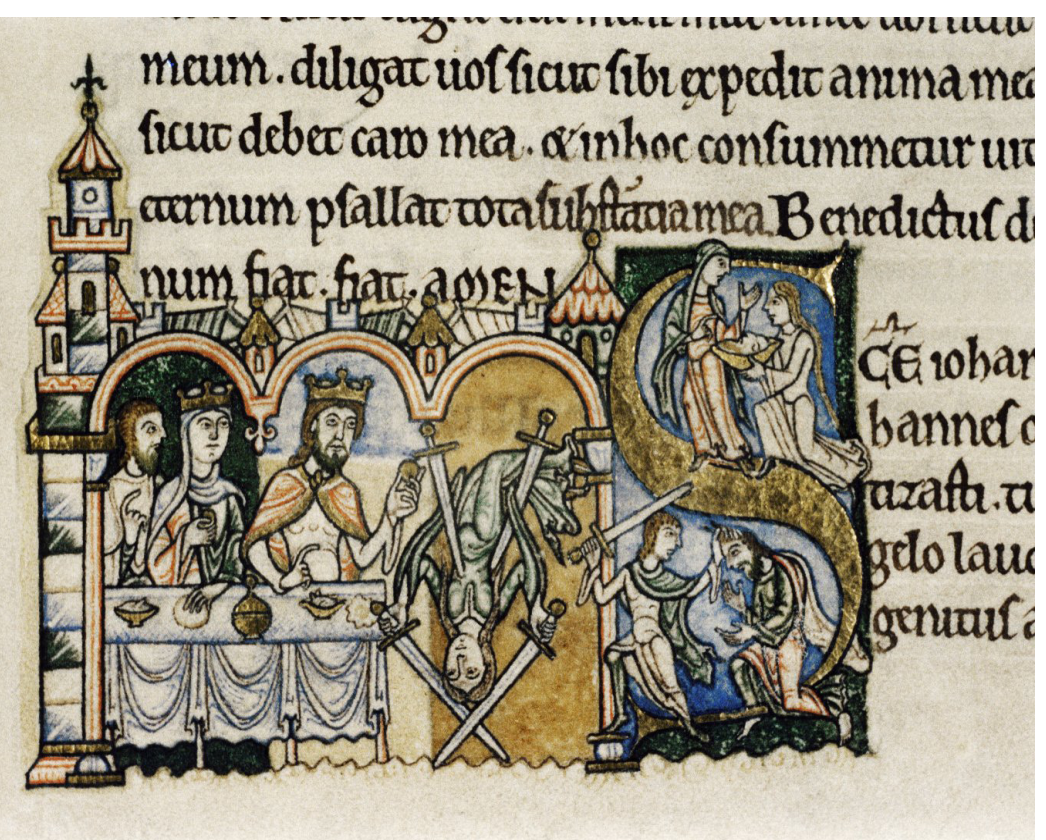

3. Oxford, Bodleian Library, ms. Auct. D.2.6, fol. I66v.

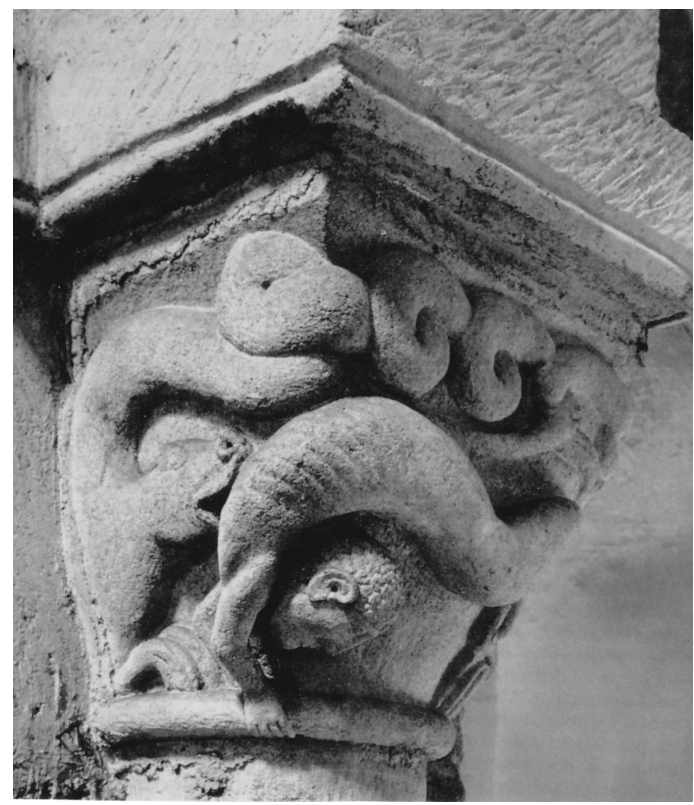

4. Iglesia de Anzy-le-Duc, capitel. 


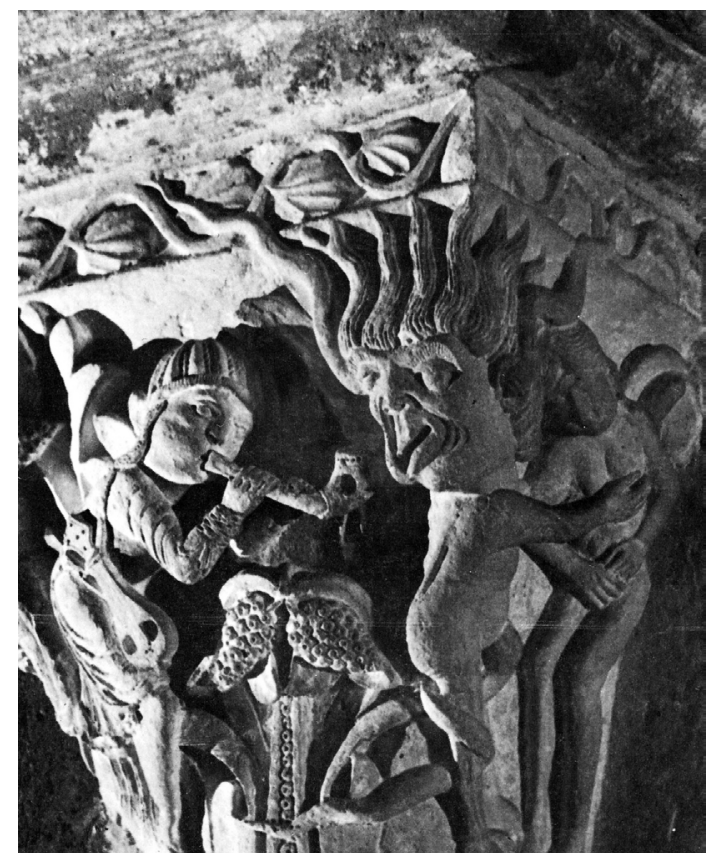

5. Vézelay, Iglesia de Sainte Madeleine, capitel.

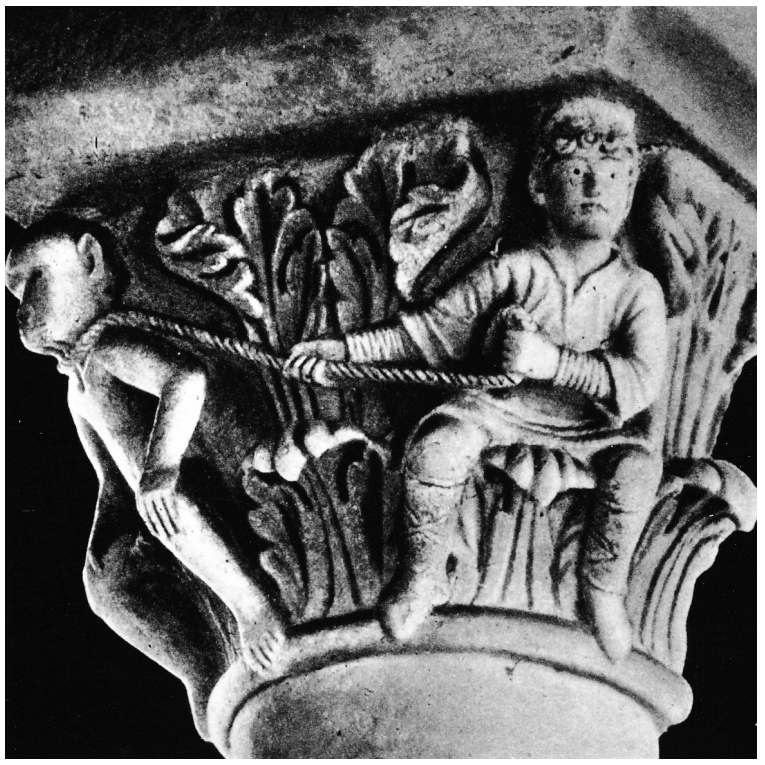

6. Iglesia de Mozac, capitel. 


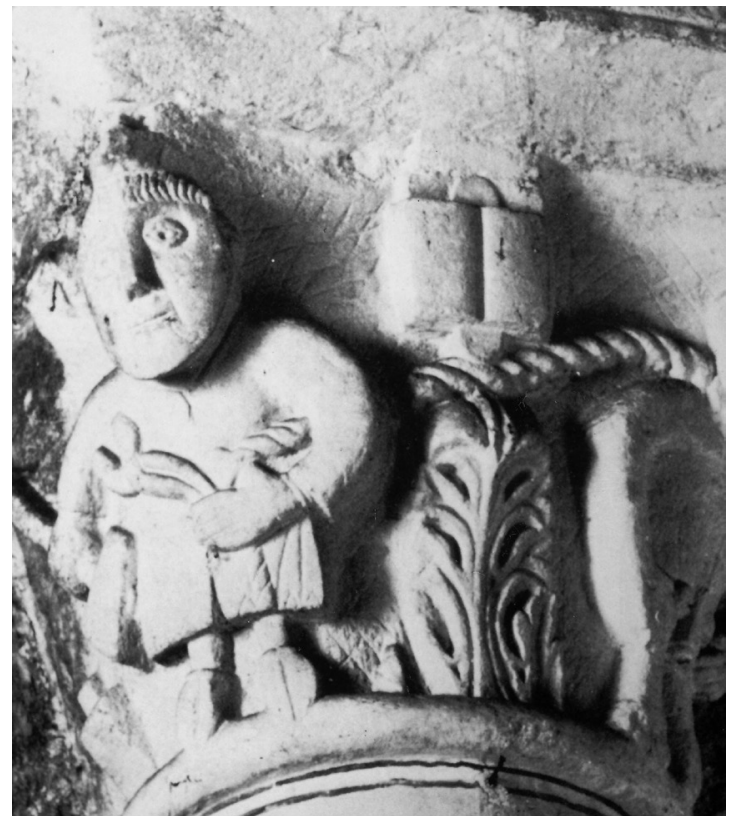

7. Iglesia de Droiturier, capitel.

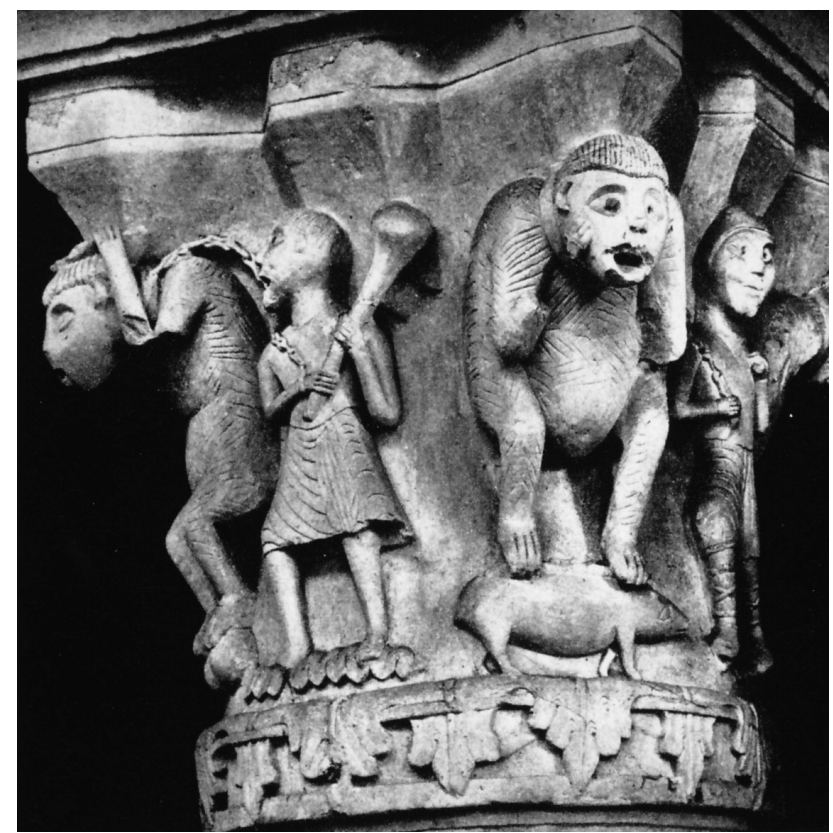

8. Iglesia de Saint-Genou, capitel. 


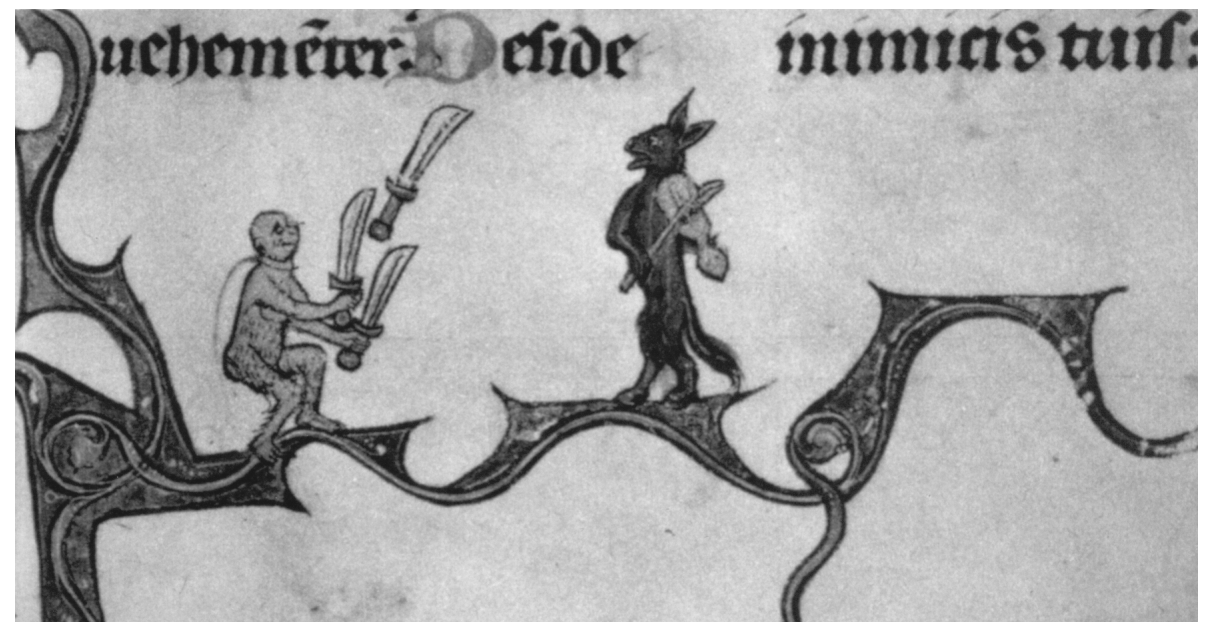

9. Baltimore, Walters Art Gallery, ms. I09, fol. 20.

is nous a ta les engrens faut osed)ier we en poes lot gare ual al uergier. 083-2. neueus mandaul auanter uns. uiu. 2028 venroit entor cos murs land th les dift callamus naves toing overnater

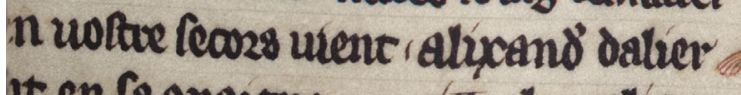
it en fappausme $x$. mille chenatier

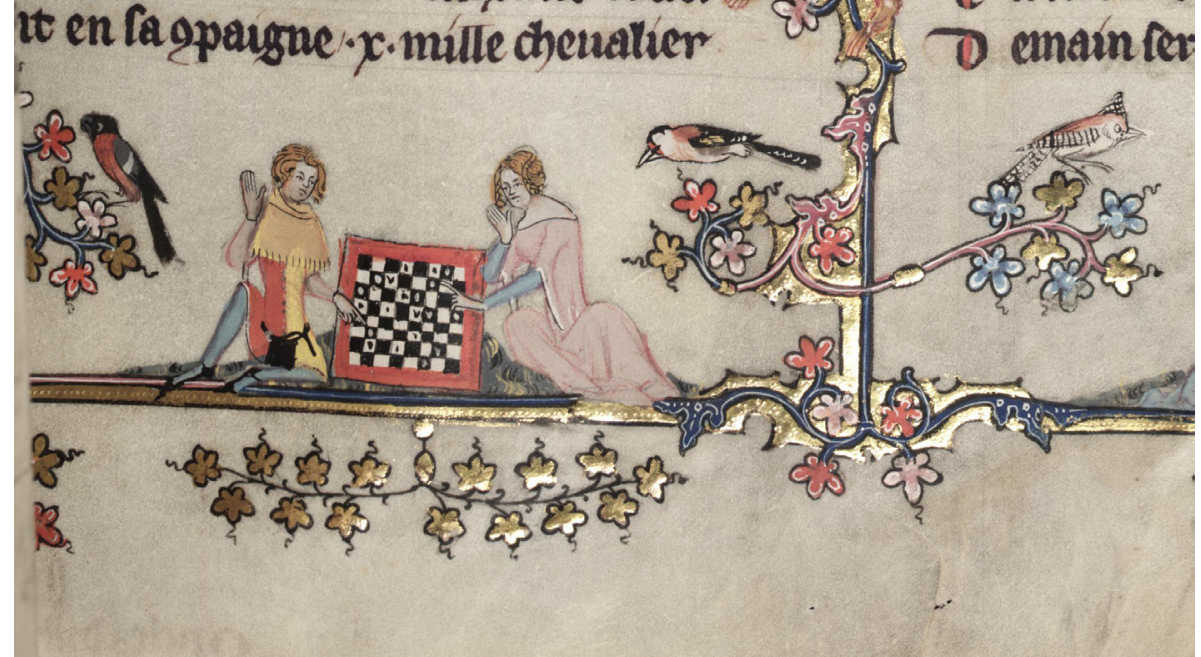

Q uul font v cerstacale ( 35 adifital Q uant tí J lles a tar ces en necours Io. Roman d'Alexandre, Oxford, Bodleian Library, ms. Bodley 264, fol. II2. 


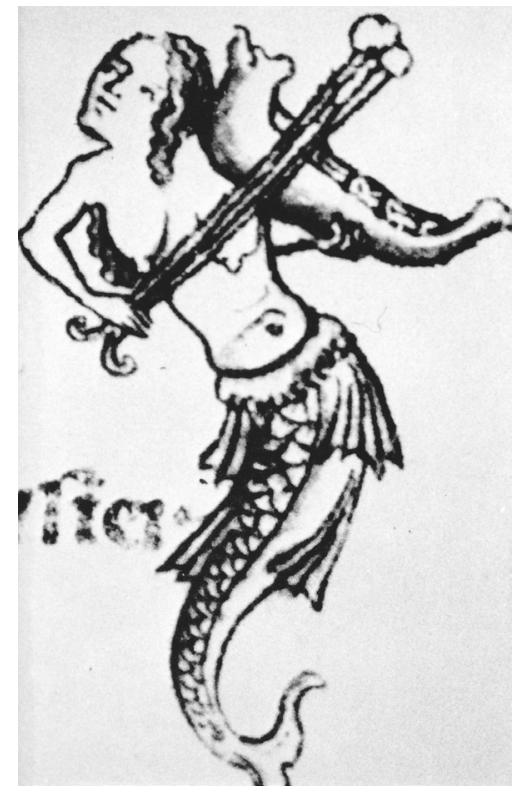

II. Jacques de Longuyon, Voeux du Paon, New York, Pierpont Morgan Library, William Glazier Collection, ms. 24, fol. I6.

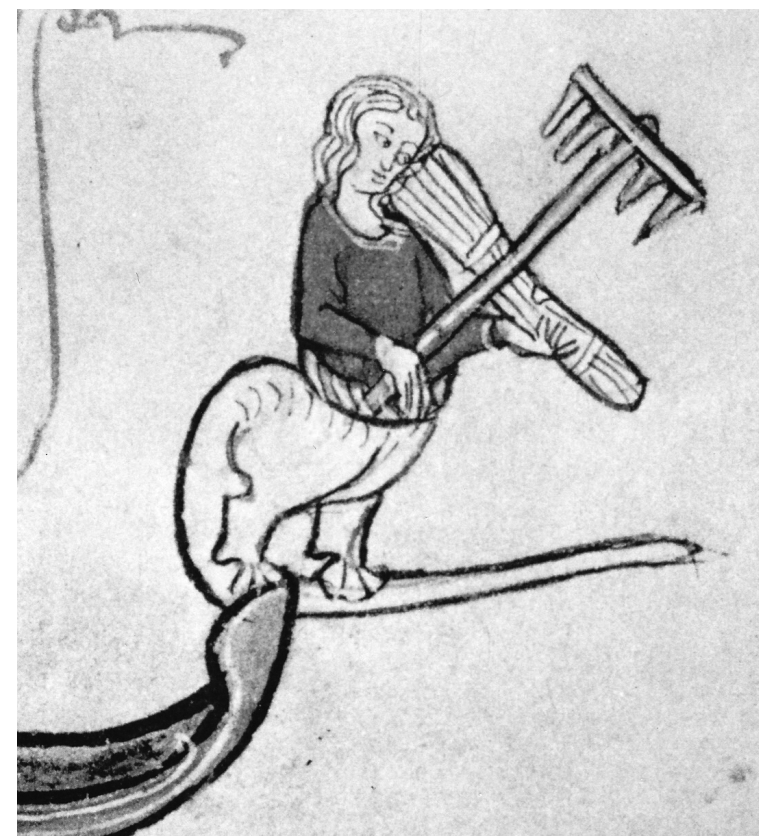

I2. Bruxelles, Bibliothèque Royale, ms. 939I, fol. II3v. 


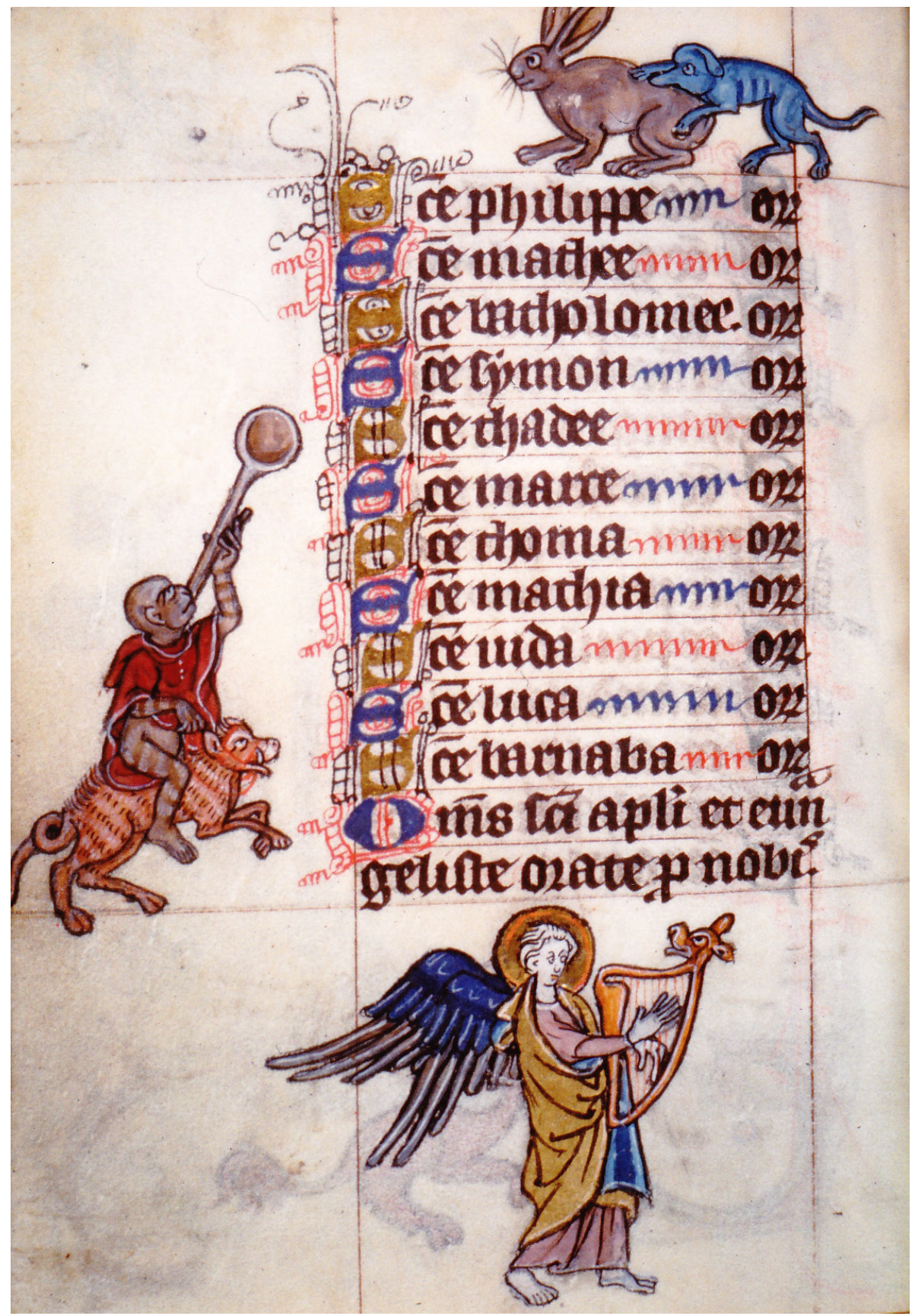

I3. Libro de Horas de Maestricht, London, British Library, ms. Stowe I7, fol. I73v. 


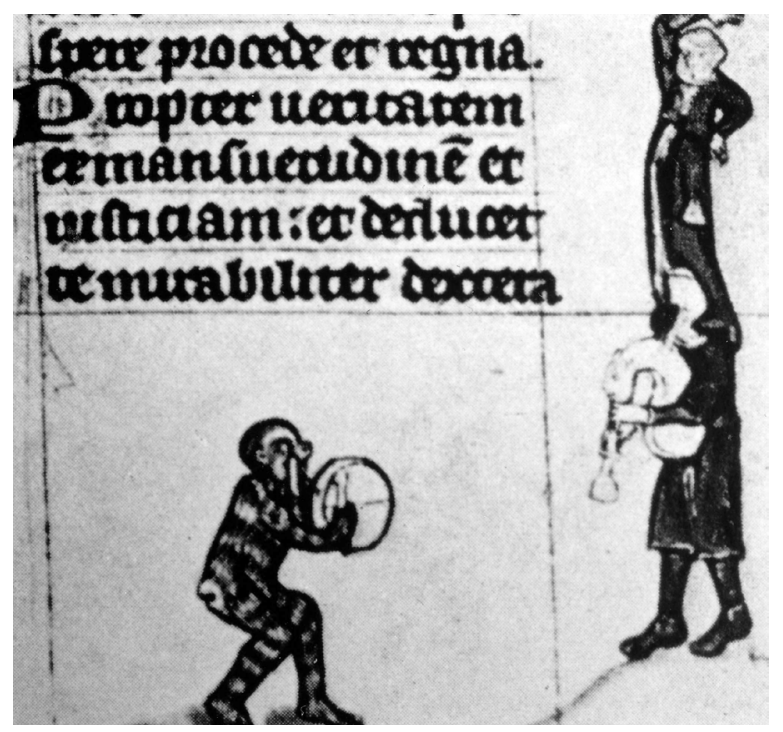

14. Libro de Horas de Maestricht, London, British Library, ms. Stowe I7, fol. 3I.

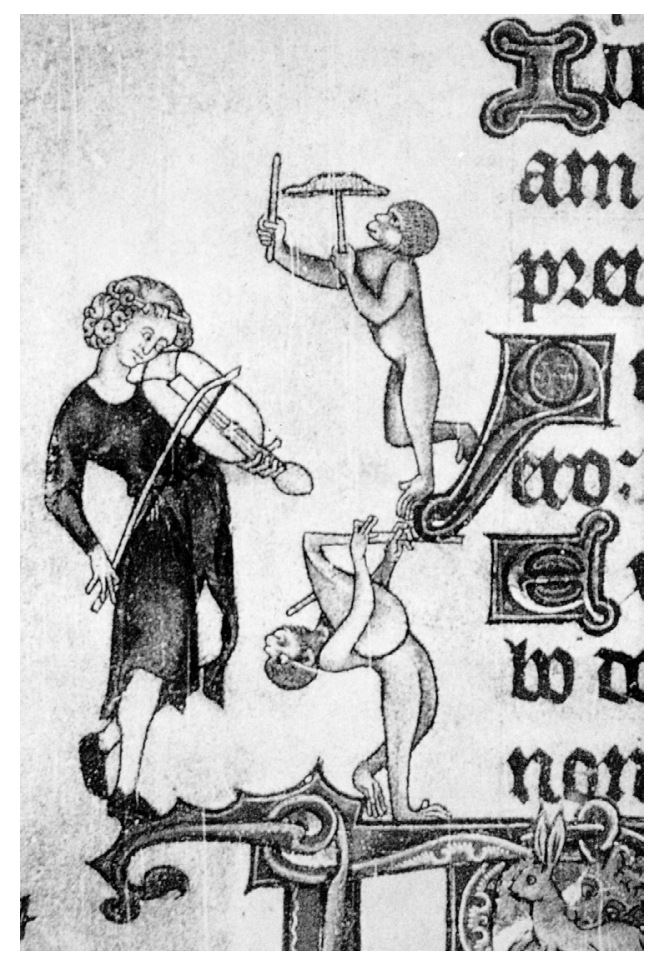

I5. Salterio Tenison, London, British Library, ms. Add. 24686, fol. I7v. 


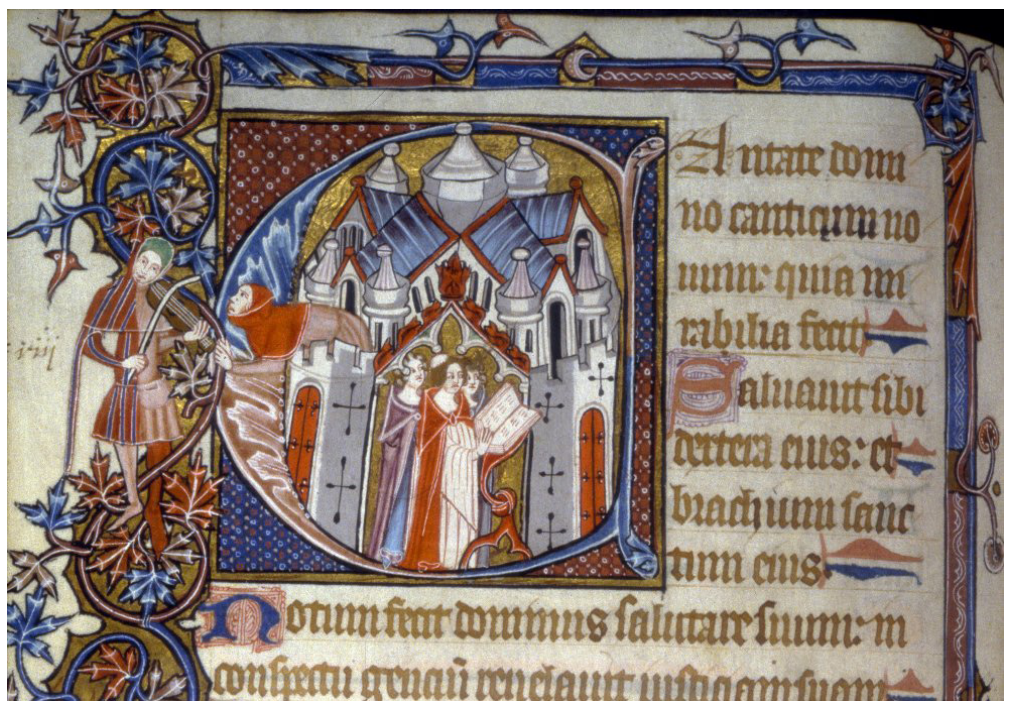

I6. Oxford, Bodleian Library, ms. Liturg. I98, fol. 9Iv.

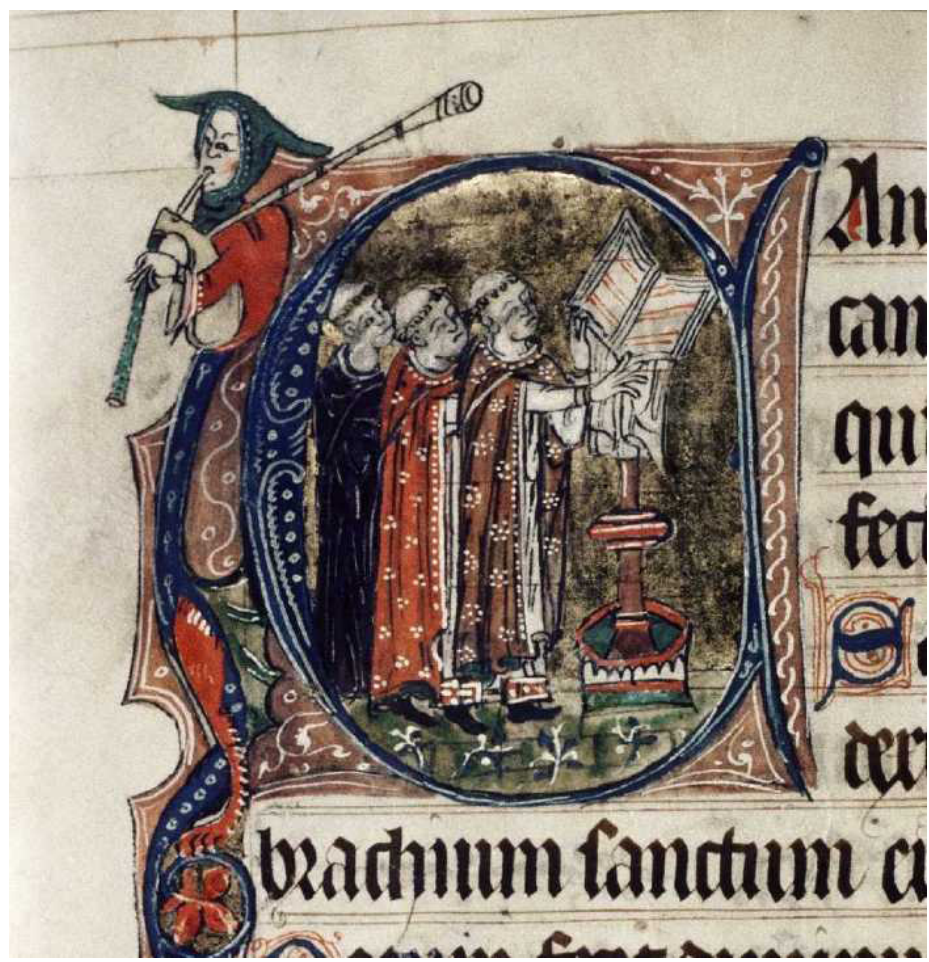

I7. Oxford, Bodleian Library, ms. Auct. D. 2. 2, fol. II3v. 


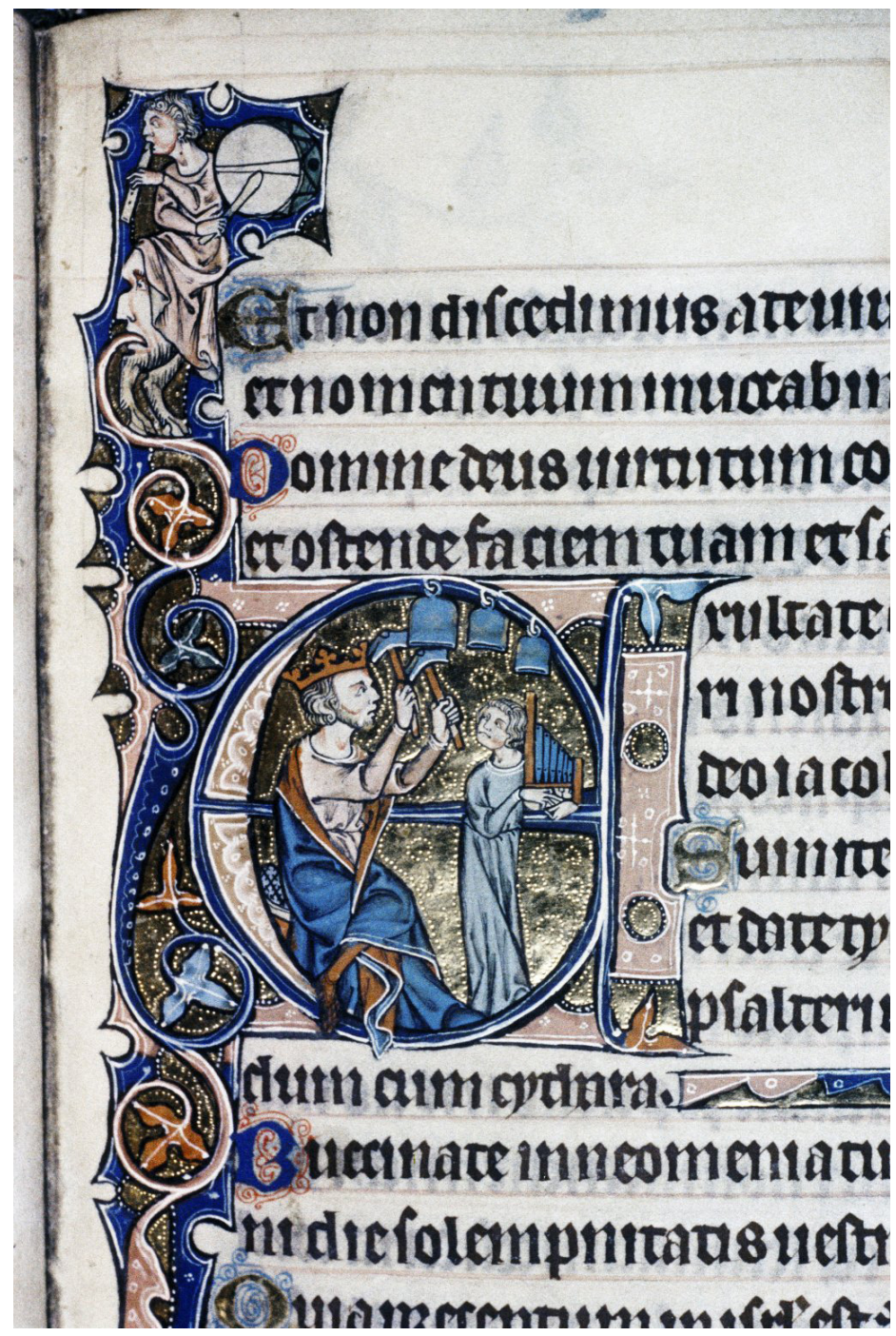

I8. Salterio Barlow, Oxford, Bodleian Library, ms. Barlow 22, fol. 99. 


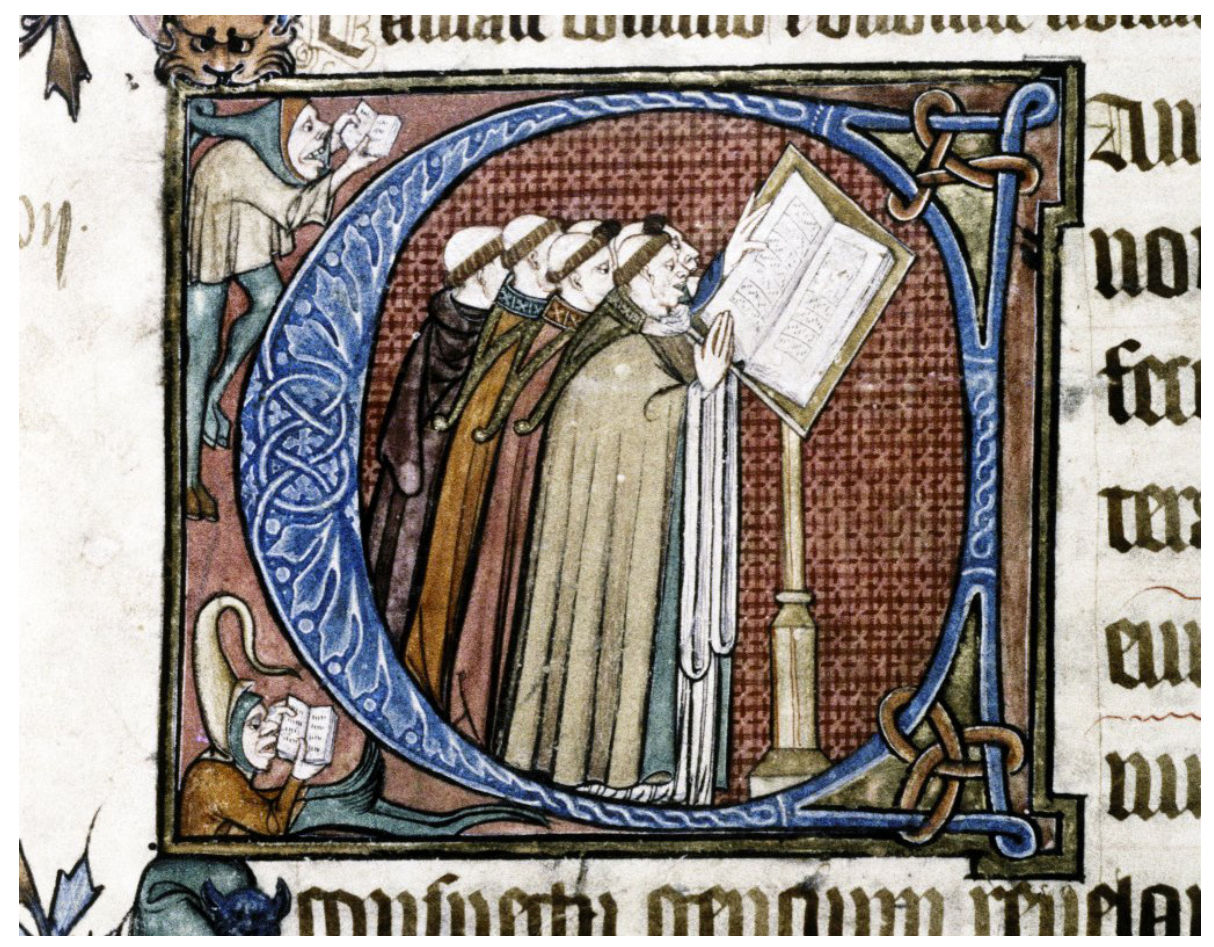

19. Salterio de Stephen of Derby, Oxford, Bodleian Library, ms. Rawlinson G. I85, fol. 8Iv. 